Carmen Neamţu*

"Aurel Vlaicu" State University from Arad, Romania

\title{
Genres of Cultural Journalism: Theatre Review
}

\begin{abstract}
:
This paper focuses on cultural journalism and its main species. After a brief review of the main genres of the cultural writing press, I will dwell on the theater chronicle, trying to see what style of writing is circumscribed and what are the main steps in writing a theatre review. Based on my 23 years of experience as a journalist in the daily generalist and specialized cultural press (Cultural Magazine of the Romanian Writers' Union, ARCA), I dare to say that the secret of any theater review lies in the balance between the information transmitted and the journalist's comment, between the statement and the argument displayed. Being a personal judgement, therefor subjective, the article can rise dissatisfaction among directors, actors, set designers etc. who do not always resonate with the journalist's verdict. My paper will provide several personal examples of approaching the theater show, situations that I have faced over time, all to shed some light on writing the theater review. From a stylistic point of view, I will try to see how theatre review differs in the overall press coverage. The editorial style of the theater review could be circumscribed to the journalistic style, having at the same time an accentuated aesthetic dimension. This brings it closer to the language of literature.
\end{abstract}

Keywords:

genres of cultural journalism, writing style of theatre review

\section{Resumo:}

Este artigo aborda o jornalismo cultural e os seus géneros principais. Após uma breve análise destes últimos, debruçar-me-ei sobre a crónica teatral, tentando caracterizar o seu tipo de escrita e descrever os principais passos envolvidos na redacção de uma recensão teatral. Baseando-me nos meus 23 anos de experiência da imprensa generalista diária e da imprensa cultural especializada (na revista cultural da União dos Escritores Romenos, $A R C A$ ), sustento que o segredo de qualquer recensão teatral reside no equilíbrio entre a informação transmitida e o comentário do jornalista, entre o elemento noticioso e o argumento exposto. Exprimindo um juízo pessoal, e portanto subjetivo, o artigo pode gerar insatisfação junto de encenadores, atores, cenógrafos, etc., que nem sempre concordam com o veredicto do jornalista. O meu artigo oferece diversos exemplos pessoais de modos de abordar o espetáculo teatral e de situações com as quais me confrontei ao longo do tempo, com vista a lançar luz sobre a escrita da recensão teatral. No plano estilístico, tentarei examinar de que modo a recensão teatral difere da cobertura jornalística geral. 0 estilo editorial 
da recensão pode circunscrever-se ao estilo jornalístico, tendo ao mesmo tempo uma dimensão estética acentuada, o que a aproxima da linguagem da literatura..

Palavras-chave:

géneros do jornalismo literário, estilo de escrita da recensão teatral

Going to the theater is a form of resistance to the advertising speech, to the soap opera, to the zaping, to the violence of SF movies. There are small concentrations of people who want to escape the majority discourse. Theatre is a minority art and it resists as a minority art. The fact that it is a minority and a local phenomenon differentiates it

(Georges Banu)

Critics are like horse-flies. They prevent the horse from ploughing.

(Anton Chekhov)

\section{Journalistic Style}

The editorial style of the theater review could be circumscribed to the journalistic style, ${ }^{1}$ having at the same time an accentuated aesthetic dimension. This brings it closer to the language of literature, which takes on characteristics from all styles of language. We can say that cultural articles embrace the "emotional function of language" and cultivate "the poetic function of the world" ${ }^{2}$ (see also Ruşti 2002: 8). I will try to synthesize the main characteristics of the journalistic style.

Thus, the style of the press must be a direct, clear, simple way for the reader to understand the text (Neamţu 2007). The style makes the reading attractive and turns the reader into an "indirect witness to the facts reported by the journalist" (Gaillard 2000: 126). The journalistic style must be simple and alive. In the table below I will present in summary the main characteristics of the journalistic style, evoked by the French professor. 


\begin{tabular}{|c|c|c|}
\hline $\begin{array}{l}\text { Simplicity of the journalistic } \\
\text { style }\end{array}$ & $\begin{array}{l}\text { The concrete, precise character } \\
\text { of the journalistic style }\end{array}$ & $\begin{array}{l}\text { The vivacity of the journalistic } \\
\text { style }\end{array}$ \\
\hline $\begin{array}{l}\rightarrow \text { This is the dominant feature of } \\
\text { the journalistic style. } \\
\rightarrow \text { It is the most difficult quality } \\
\text { to obtain and it focuses primarily } \\
\text { on vocabulary. (p. 128) } \\
\rightarrow \text { Grammatical simplicity requires } \\
\text { avoiding the use of a difficult and } \\
\text { precious topic (p. 128) }\end{array}$ & $\begin{array}{l}\rightarrow \text { It is helpful for the rigor with } \\
\text { which the information is to be } \\
\text { treated. } \\
\rightarrow \text { The slightest trace of useless } \\
\text { talk will distract the reader and } \\
\text { "remove" him from the text. } \\
\text { (p.128) } \\
\rightarrow \text { Every sentence and almost } \\
\text { every word must bring an } \\
\text { element of information. Thus } \\
\text { the importance of the selection } \\
\text { and precision of each noun or } \\
\text { adjective, of the systematic } \\
\text { elimination of any vague or } \\
\text { unnecessary adjectives } \\
\text { adverbs. (pp.128-129) } \\
\rightarrow \text { Avoid vague words, overused to } \\
\text { the point of exhaustion, used on } \\
\text { their own, without explanation: } \\
\text { fascinating, interesting, amazing, } \\
\text { beautiful, cool, wonderful, } \\
\text { marvellous, glorious, gorgeous, } \\
\text { nice, feisty, funny, amusing } \\
\text { boring, uninteresting, ugly, awful, } \\
\text { unfunny. }\end{array}$ & $\begin{array}{l}\rightarrow \text { Simplicity and precision give the } \\
\text { style a certain vivacity. (p.129) } \\
\rightarrow \text { To be lively, to capture the rea- } \\
\text { der, Gaillard recommends: wri- } \\
\text { ting in the present tense, inserting } \\
\text { quotes, visual images and compa- } \\
\text { risons into the text. }\end{array}$ \\
\hline
\end{tabular}

The Romanian philosopher Andrei Pleşu, analyzing the Romanian journalism, finds a "talkativeness in the style of the written press" (Pleşu 1997). He distinguishes between two styles: the didactic style and the satirical style of writing. The didactic style reveals a delirium of competence and demagoguery. Placed high above stupidity, the journalist knows and gives advice. He's worried, arrogant, priggish. The satirical dominance of the press discourse is that in which the journalist no longer officiates pedagogically. He chooses a more relaxed style, full of insinuations. Vulgarity is the effect that accompanies this style. The journalist cultivates a tavern colloquiality, is the analyst's opinion. 
Trying to conclude, I would say that the journalistic style must place the press article between the pleasure of reading and the exact information of the reader (Neamţu 2007: 178). To say a lot in a few sentences and in the most attractive way possible, here is the secret of a successful press text

\section{Genres of Cultural Journalism}

For didactic reasons, we will divide the species of cultural journalism into two main categories: narrative species (short news, report, serial, portrait) and non-narrative species (essay, manifesto and program, analysis and commentary of the event - editorial, review, chronicle, pamphlet, interview, polemic article, open letter) (Ruşti 2002:11-12; Husson, Robert 1991:51). In this context, the chronicle is the species that records and commnents on the show (theater, film, fashion show), thus having a dual role, informing and rendering the atmosphere through the journalist's comments. Basically, the journalist has the task of reconstructing for the reader the theater show he/she attends.

According to professor Michel Voirol (1992:66), the cronicle is a personalized commentary article, written by a well-known person and whose appearance is constant. The analyst José de Broucker (1995: 218) considers that the chronicle involves a heated discussion about a fact of life, even a trivial one. The chronicle must prove erudition and originality in an unostentatious approach.

Romanian professor Sorin Preda (2006: 186) recalls the etymology of the word chronicle, that comes from the Greek cronos, time, to circulate information. In order to clarify the specifics of literary analysis professor Ştefan Cazimir compared it to the chemical analisys. He draws attention to the importance of the journalist in the writing process. The solution of the chemical analysis does not depend on the person who performs it, being a "closed analisys". In literary analysis we speak of the subjectivity of the one who undertakes it. The same text generates a number equal to the number of those who lean on it. Literary analysis is an open one, because it does not exhaust its object. We will never say about a certain text that everything that could be said was said (Cazimir 2020:3).

We could summarize that the theater review, like the literary analysis, involves some decisive operations from journalist, his/her culture, his/her erudition being important in the elaboration of the text, in explaining the relation of the play with the author, other similar texts /stagings, other genres approached by the author etc.

Analyzing the local Romanian cultural press, I would say that the situation changed dramatically with the crisis of 2007. The crisis changed the structure of local Romanian newspapers, which almost abandoned the cultural subjects. To better understand, I briefly present the situation at my local newspaper were I was working at the time. "Observator" newspaper had a whole page dedicated to culture three times a week. The theater performances were on Sunday and the newspaper was waiting for the review of sunday's show to appear on Monday newspaper. All the pages included extensive interviews in the cultural area but also book reviews. Every autumn, Arad, my hometown, hosts a classical theater festival, with 
international participation. Every day, on the front page, my local newspaper had a reference to the festival and inside, a culture page that covered the event, with reviews, interviews with artists, etc. With the crisis of the written press, from 2007-2008, many of the local publications closed. To give you an idea, there are only two newspapers in the city of Arad. The rest went bankrupt. The press has moved online. ${ }^{3}$

Under these sad conditions, cultural journalism in the local generalist press collapsed. It disappeared slowly. The only cultural information that remains is related to sensational topics: how much smoke the director used in the play, how big the writer's book is, how the actor was caught in an indecent posture etc. Cultural backstage, spicy and juicy info prioritize. So we can not say that local press is giving a direction to the reader and provide a guide to navigate the existing cultural offerings in the city.

Articles in the cultural pages of local newspapers adopt from a stylistic point of view a mixture of fiction-artistic style, with the editorial requirements of brevity, not forgetting language clichés, such as "manifestation of soul", "show / cultural event / interesting project". The interesting qualifier, more and more frequently in writing, is not transmitting anything about the event. It is a convenient term, which saves the journalist from thinking about the subject he is writing about. It becomes a flattering word in opposition to "a salt and pepperfree event", meaning uninteresting, flat manifestation. The interesting adjective stands on the same pedestal as provocative and challanging.

More and more often, local journalists choose the simplistic way of giving copy-paste to materials developed by the public relations office of the cultural institutions they are talking about. Referring to the theater review in the Romanian local or provincial papers, it was replaced by news stuffed with a few adjectives related to the theater show. The local journalist emphasis on lively entertaining reading. "It's a show you shouldn't miss", or "you must go to see this play". Imperative verbs stand in place of a coherent text that should lead the reader to choose theater and nothing else in his spare time. A lamentable step on the part of the journalist. As professor Hennessy wrote, "arts coverage blurs into showbiz gossip". (Hennessy 1997:309)

Two major flaws lurk in this journalistic approach. Professional indifference, boredom and preciousness, excess of ornaments, neologisms, standardized formulas in writing. Although the critic ${ }^{4}$ needs a vast and solid culture, he must not overwhelm his reader with his erudition. During all this time since I have been working in the press, I can say that I have learned to establish several degrees of exigency. For beginners or established artists. That is why I consider it important to keep a reservation before pronouncing the verdict. And take into account the evolution of the artist over time. Cultural journalism requires careful documentation of the journalist, a fair amount of reading up on the subject and the artists's work. The press releases available from the publicity agents are not to be neglected. But they should not be the journalist's only source.

As professor Hennessy points out, because of the differences in perspective ${ }^{5}$ it's often difficult to pin down what is fair and what is unfair comment. That is why the reviewers need some essential attributes (see Hennessy 1997:308). 
- Knowledge o the field being written about.

- A passion to know and experience more

- A desire to share your passion and knowledge with readers

- The ability to judge perceptively

- The courage to stand by convictions against pressure to please those with other premises

- The writing skill to communicate vividly and entertainingly

- The writing skill to make the assessment clear to the readers

\section{Challenges of Theater Criticism}

The construction of the critical text has several obligatory points: the contextualization of the author and the work, a short summary, the emphasis of the novelty, the valorization of the work. Here are some questions to answer (Hennessy 1997:310):

- What is it called?

- What's the genre?

- What is it about? What does it mean? What does represent?

- What is it like?

- Who created it?

- Who directed it?

- Where is it showing? When and where does the action take place?

- Why was it written/directed?

Answering these questions, your opinion must be informed and you must show it to be informed by indicating the evidence for your statements and arguments. The evidence will be in the form of facts, examples, quotes. "It's a question of integrity. You react to the work, you analyse your reaction, make your assessement and communicate it honestly" (Hennessy 1997: 311. See also Bloom 1985: 186).

-What are the work's merits/defects?

- Is it worth your time and money?

- Did I like it?

- Will you like it?

-What sort of people will like it?

- Is it informative/inspiring/interesting/entertaining?

- What are the significant elements and how do they compare generally with other works in the genre (plot or characters, well-made play or post modern experiment, message or slice of life?

- How far does the creator succeed in achieving what they set out to do?

- How well has the work been served by the interpreters invorlved - actors, directors, set designers, musicians etc.?

- If known (e.g. last night's theatre), how did the audience react to the work? 
For didactic reasons, here is a short outline that can be followed:

- Contextualizing the play and its author

- Subject in brief

- The construction of the show

- Strong directing elements that support (or not) the written text

- Innovations in scenography, directing, lighting, music

- The message of the play for today's audience

The critic has long been a reviled figure, at best the mere handmaiden of the "creative" arts, at worst a parasite upon them. For Brendan Behan, critics are like eunuchs in a harem. They know how it is done. They have seen it done every day. But they are unable to do it themselves. In an age of book clubs, celebrity endorsements and bloggers, what role is there now for the professional critic as an arbiter of artistic value? Are literature and the arts merely a question of personal taste? Is one opinion "as good as another"? Rónán McDonald's The Death of the Critic (2009) seeks to defend the role of the public critic. He argues against recent claims that all artistic value is simply relative and subjective. ${ }^{6}$

How do you see the purpose and importance of theater criticism today? This question was part of a survey initiated by the Romanian magazine of the Writers' Union of TârguMureş, "VATRA". ${ }^{7}$ I will summarize some of the guest responses. Marian Popescu talks about a repositioning of theatrical criticism in the world, due to the disappearance of the print media and the appearance of online versions. Professor Mircea Morariu is convinced that the purpose and importance of criticism have always been the same: to judge and to testify. The big problem is that we don't have critics. People with suitcases always ready to hit the roads of the country in search of remarkable theatrical facts. Theater criticism is more necessary than ever thinks Emil Boroghină. It has a duty to sound the alarm, to wake up all. The purpose of criticism is not only to find, to x-ray, but also to suggest directions. For Cristina Modreanu, critical thinking is more important today than ever before, in an age of professionally practiced media manipulation. In this context, the contemporary critic who really matters and has an influence is the one who masters well the new methods of communication, who carefully manages not only his public presence, but also the online space and is able to adjusts his speech according to the channel through which he transmits his message. For professor Miruna Runcan, theater criticism survives, today, as a pure semi-voluntary exercise. For critic, it is a permanent balance between subsistence and a desperate effort to cover current theatrical realities.

In order to better understand the structure of a review I will give you an example:

\begin{tabular}{|c|c|}
\hline $\begin{array}{l}\text { Here's what you need to keep in mind: } \\
\text { - What is the name of the play? } \\
\text { - What's the genre? (Literary novel or thriller, } \\
\text { tragedy or comedy etc.) } \\
\text { - What is it about? }\end{array}$ & $\begin{array}{l}\text { "Ioan Slavici" Classical Theater from Arad } \\
\text { Romania; "L'Affaire de la rue de Lourcine" } \\
\text { by Eugène Labiche. Translation: Violeta } \\
\text { Popa. Directed by Alexandru Mâzgăreanu. } \\
\text { Scenographer: Romulus Boicu. Costumes: }\end{array}$ \\
\hline
\end{tabular}



- As a reviwer I always read the text as a preliminary research.
- The reviewer might want to discuss whether or not justice was done to the text. whether or not justice was done to the text.

- The period or periods of the play. Is it about today, or a century ago?

- How does the author use time? Is the sequence clear or confusing for the public?

"The story is what happens; the plot is the structure of what happens with the causality indicated". (Hennessy 1997: 316)
Alexandra Mâzgăreanu. Music: Alexandru Suciu.

The play is a boulevard comedy with: Ștefan Statnic, Cecilia Lucanu - Donat, Alex Mărgineanu, Marian Parfeni and Ioan Peter.

Considered a forerunner of surrealism and absurd theater, Eugène Labiche (1815-1888) was one of the most prolific comedians of the nineteenth century. Literary critics have noted his impeccable theatrical technique and caricatured sense in portraying the world of the bourgeoisie of his time.

Eugène-Marin Labiche was a comic playwright who wrote many of the most popular and amusing light comedies of the 19th-century French stage. Though full of dramatic devices, Labiche's plays show real insight into human nature. The best of his works include Le Chapeau de paille d'Italie (1851; The Italian Straw Hat), which inspired René Clair's classic film of the same name (1927); Le Misanthrope et l'Auvergnat (1852); Le Voyage de M. Perrichon (1860; The Journey of Mr. Perrichon); and La Poudre aux yeux (1861; "The Bluff").

The comedy "L'Affaire de la rue de Lourcine" - a play in an act, was first performed in 1857, and was hailed as "a fierce and enchanting joke."

After a drink, Lenglumé wakes up the next day with a terrible headache and a lost monkey umbrella. Next to him sleeps an unknown man, who turns out to be his former colleague, Mistingue. At the table, his wife reads to him from the newspaper about a murder. A woman is killed, and men are convinced that they are criminals, especially since they discover incriminating objects in their pockets: a piece of charcoal, a loop, a woman's shoe. Misled by an article in an old newspaper, the 


\begin{tabular}{|c|c|}
\hline & $\begin{array}{l}\text { two men channel their energy to save their lives at } \\
\text { all costs. Compromising evidence must disappear } \\
\text { and murder witnesses must be removed. }\end{array}$ \\
\hline $\begin{array}{l}\text { - Characterization and conflict } \\
\text { - Readers want to be persuaded memorably } \\
\text { - Embrace the writing skill to communicate vividly } \\
\text { and entertainingly. } \\
\text { "The theme, or message behind the story, may } \\
\text { have to be carefully distinguished from the story } \\
\text { itself". (Hennessy 1997: 316) } \\
\text { - The setting - the place, the ambience, the } \\
\text { atmosphere. }\end{array}$ & $\begin{array}{l}\text { Director Alexandru Mâzgăreanu conceives the } \\
\text { staging around the lost green umbrella, which } \\
\text { sits, oversized, in the center of the stage. Around } \\
\text { it grows the paranoia of the characters, who do } \\
\text { anything but get out of this mess. "What drew } \\
\text { me to the Lourcine Street Crime, beyond the } \\
\text { existence of an extremely well-developed comic } \\
\text { mechanism, with reversals every half page and } \\
\text { gags at almost every line, was the fact that he } \\
\text { speaks with a lot of cynicism about a problem. } \\
\text { of morality ", confesses the director of the play, } \\
\text { Alexandru Mâzgăreanu. }\end{array}$ \\
\hline $\begin{array}{l}\text { "The language of reviews must get across the } \\
\text { atmosphere of the product and the reviewer's } \\
\text { place in the world described, but with a scalpel } \\
\text { rather than a sledgehammer". (Hennessy 1997: } \\
\text { 323) }\end{array}$ & $\begin{array}{l}\text { The director shows flair in choosing the actors } \\
\text { to serve his work. Ştefan Statnic plays nuanced, } \\
\text { without losing his composure during the progress } \\
\text { in "confusion". Lenglumé is a role he leads } \\
\text { intelligently and which gives him the opportunity } \\
\text { to communicate not only through words. His } \\
\text { mime, his gestures are studied, and the result is a } \\
\text { fresh, funny character. }\end{array}$ \\
\hline $\begin{array}{l}\text { - Research on director, } \\
\text { scenographer, find the time to make acquaintance } \\
\text { with previous works of the artists. } \\
\text { - Don't skip the conclusion to the review. Did I lke } \\
\text { it? } \\
\text { - Over the years I learned that what you need is } \\
\text { honesty, the bravery to say what you really feel } \\
\text { and you have to forget about being liked by artists } \\
\text { or director of the play. } \\
\text { - What are the work's merits/defects? } \\
\text { - Is it worth your time and money? }\end{array}$ & $\begin{array}{l}\text { Alex Mărgineanu, in the role of his friend } \\
\text { Mistingue, fails to overcome the "hangover" } \\
\text { stage and remains in a linear, flat role, compared } \\
\text { to the sparkling Lenglumé, but can be perfected. } \\
\text { Marian Parfeni (Justin) and Cecilia Lucanu- } \\
\text { Donat (wife Norine) manage to be spots of color } \\
\text { in the show. The diction helps them, and the very } \\
\text { successful costumes complete the elegant space } \\
\text { of the piece. Ioan Peter (Potard), with a mustache } \\
\text { and a joben, looks descended from a surreal } \\
\text { picture. Accomplice or profiteer of the situation, } \\
\text { the actor crosses the stage and brilliantly supports } \\
\text { the comedy of situations. }\end{array}$ \\
\hline
\end{tabular}




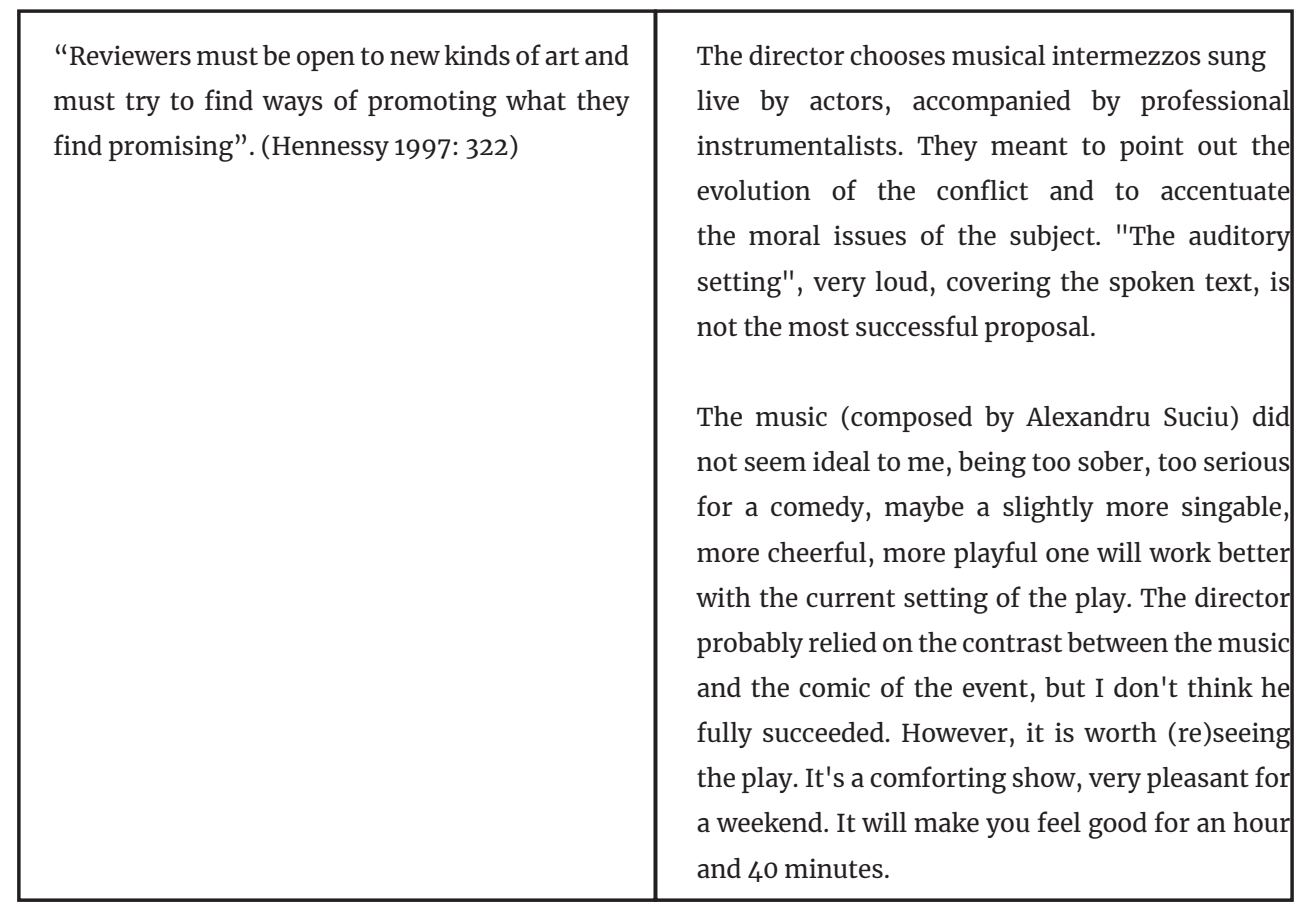

In an essay signed by Georges Banu, ${ }^{8}$ in which he radiographed the current world, the critic noted an aspect that should give us food for thought: our society will be like medieval society, barbarism around and in the middle oases of culture. Theater remains such an oasis in our society. From the current theater I expect a state transformation. To leave differently than I came. With a different energy. The Romanian director Andrei Şerban observes the lack of catharsis in today's theater. "Frequently we go home with an even more bitter taste. As if life weren't bitter enough, we go to the theater to get another cudgel into our heads". Thus been said, as Hennessy agreed (1997:307), reviewers perform a most useful task in writing about a play. They can help the artist's audience to appreciate the art fully and promote the art. Promoting the art that deserves to be promoted means identifying the art that, in the reviewer's opinion, does not. This is what reviewer tries to do and if he/she succeeds the public is the one who wins from the critic's approach. 


\section{NOTES}

* Carmen Neamţu, Ph.D., Habil., is an associate professor at at the Faculty of Humanistic and Social Sciences at "Aurel Vlaicu" State University of Arad, Romania. Ph.D. magna cum laude from 2002. Co-authored of the Handbook for Journalism, Iaşi, Ed. Polirom, 2009. Member of the editorial board of the Professional Association of Writers`s Journal, „ARCA”. Member in the editorial board of Romanian Journal of Journalism and Communication (Faculty of Journalism and Mass Communication, Bucharest University, Romania). Member of Romanian Association of Professional Journalists and of the Association of Training Experts in Journalism and Communication - Romania.

${ }^{1}$ More on this subject: see Carmen Neamţu, "Journalistic style", in Manual de jurnalism, 3rd edition, Iaşi, Polirom, 2009, pp. 170-189.

${ }^{2}$ If the main concern of the journalist is to inform, that of the writer is to transfigure reality in a truthful way (Ruşti 2002: 11-12).

${ }^{3}$ In 2020 appeared The Multimedia Dictionary of the Romanian Theater DMTR that currently contains 50 multimedia files covering the period 1950-2020. The dictionary has two sections, artists and performances and includes 50 files about actors, directors, scenographers, critics and about a series of performances that are landmarks of the Romanian theater from the second part of the 2oth century. The dictionary can be a viable source of documentation for cultural journalists at https:// www.dmtr.ro, last accessed 6.08. 2020.

4Professor Brendan Henessy (1997: 307-308) distinguishes between reviewers (if they work in journalism) and critics (if they are academics). All of them can help the author's audience to "appreciate the art fully and thus promote the play" (p. 307). What you need is honesty, the bravery to say what you really feel ... you have to forget about being liked.

${ }^{5}$ Ibidem. "Artists complain that reviewers do not know what they're are talking about because they haven't done it".

${ }^{6}$ A conference on this topic was presented between 22-23 november 2018, at University of Copenhagen, Denmark. the topics of discussion showed that cultural journalism and cultural critique today take up many different stylistic formats and comprise many different voices. The increasing heterogeneity of cultural arbiters of taste includes cultural consumers, bloggers, celebrities, cultural journalists, media professionals, pundits, academics and intellectuals, who perform and (re) negotiate culture critical authority and expertise in different ways. They mix various types of emotional, experience-based or subjective reactions to culture, performed bottom-up, with aesthetics knowledge and expertise about arts and culture - and their presence in the culture critical circuit calls for new types of research questions and approaches to the study of cultural journalism and cultural critique.

${ }^{7}$ https://revistavatra.org/2020/05/05/teatrul-romanesc-azi-partea-a-ii-a/last accessed at 31.07.2020.

${ }^{8}$ Journalist Monica Andronescu interviewing prof. Georges Banu, https://jurnalul.antena3.ro/campaniile-jurnalul/romanicare-mai-au-de-spus-ceva/george-banu-a-merge-la-teatru-si-aici-si-in-occident-e-o-forma-de-rezistenta- 575499. html. last accessed at 13.08.2020. Georges Banu was born in June 1943 in Buzău, Romania, and is a well-renowned theatre personality and critic. He studied at the Academy of Drama and Film in Bucharest, and permanently moved to Paris in 1973. Professor I.E.T. (Institut d'Etudes théâtrales) at the University of Paris III, Sorbonne Nouvelle in Paris and at the Theatre Studies Faculty of the University of Louvain la Neuve in Belgium, Banu founded the Experimental Theatre Academy in Paris in 1990, together with Michelle Kokosowski, which he ran until 2001, when the Academy's activities ended. 


\section{Works Cited}

Bloom, Lynn Z. (1985), Fact and Artefact. Writing Nonfiction, New York, Harcourt Brace Jovanovich Publishers.

Cazimir, Ştefan (2020), Art."Ce este analiza literară", in "România literară", No.29-30, An.LII, 17.07.2020, p.3.

Gaillard, Philippe (2000), Tehnica jurnalistului, Bucureşti, Ed.Ştiinţifică.

Hennessy, Brendan (1997), Writing Feature Articles, Oxford, Focal Press.

Husson, Didier /Olivier Robert (1991), Profession Journalist, Paris, Eyrolles.

McDonald, Rónán (2009), The Death of the Critic, Bloomsbury Academic.

Neamţu, Carmen (2007), Limbă şi stil în presa scrisă, Arad, Ed.Mirador.

--(2009), Cap. "Stilul jurnalistic", Manual de jurnalism, 3rd edition, Iaşi, Ed.Polirom, pp. 170189.

Pleşu, Andrei (1997), Art. "Stil gazetăresc", "Dilema" No 239, 22-28. 08.1997, p.3.

Preda, Sorin (2006), Jurnalismul cultural, Iaşi, Ed. Polirom.

Ruşti, Doina (2002), Presa culturală. Specii, tehnici compoziţionale şi de redactare, Bucureşti, Ed.Fundaţiei PRO.

Voirol, Michel (1992), Guide de la rédaction, Paris, CFPJ. 